\title{
Produksi Benih Sintetik Teh Camellia sinensis
}

\author{
Alvhi Widya Calandry, Wirdhatul Muslihatin, dan Sutini \\ Departemen Biologi, Fakultas Ilmu Alam, Institut Teknologi Sepuluh Nopember (ITS) \\ e-mail: w_muslih@bio.its.ac.id
}

\begin{abstract}
Abstrak-Teh (Camellia sinensis) memiliki kandungan dan manfaat yang banyak, sehimgga diperlukan alternatif untuk mendapatkan benih teh dalam waktu yang singkat dan dalam jumlah banyak. Salah satu alternatif adalah dengan melakukan perbanyakan tanaman secara vegetatif melalui pendekatan bioteknologi yaitu teknik Kultur in Vitro dan teknik enkapsulasi embriosomatik yang dapat menghasilkan benih sintetik. Tujuan dari penelitian ini untuk produksi benih sintetik dari embriosomatik guna penyediaan benih yang dapat disimpan dalam waktu yang lama. Benih sintetik Teh dengan bahan tanam embriosomatik yang dienkapsulasi menggunakan alginat $4 \%$ sehingga kapsul tidak terlalu padat dan memungkinkan benih dapat tumbuh dan berkecambah. Karakteristik benih sintetik yang dihasilkan yaitu tekstur benih sintetik padat namun tidak terlalu keras, masih rentan rusak apabila tidak hati-hati ketika memindahkan.. Benih sintetik berwarna hijau kekuningan dengan diameter 5,5-5,7 mm dan berat basah $260-290 \mathrm{mg}$.
\end{abstract}

Kata Kunci-Alginat, Benih sintetik, Embriosomatik, Enkapsulasi.

\section{PENDAHULUAN}

$\mathrm{K}$ ONSUMSI teh (Camellia sinensis) di Indonesia sudah sangat dikenal secara turun menurun dan diketahui manfaatnya, bahkan konsumsi teh di Indonesia terus meningkat dari 68.000 ton pada tahun 2009 menjadi 98.000 ton pada tahun 2013. Produksi teh di dalam negeri adalah sebesar 144.000 ton pada tahun 2013 [1].

Senyawa utama yang dikandung teh adalah katekin, senyawa ini mengandung antioksidan karena gugus fenol yang dimilikinya [2]. Beberapa vitamin yang dikandung teh diantaranya adalah vitamin $\mathrm{C}$, vitamin $\mathrm{B}$, dan vitamin $\mathrm{A}$ [3] . Dengan mengetahui kandungan dan manfaatnya, konsumsi teh meningkat sehingga dibutuhkan peningkatan produksi teh untuk memenuhi permintaan pasar.

Saat ini, perbanyakan tanaman teh di indonesia masih menggunakan stek batang, namun terdapat kelemahan pada metode ini yaitu membutuhkan pohon induk yang lebih besar dan lebih banyak, akar tanaman kurang kokoh, masa produktif singkat dan membutuhkan biaya yang mahal [4].

Salah satu alternatif untuk meningkatkan produksi teh tersebut adalah dengan melakukan perbanyakan tanaman secara vegetatif melalui pendekatan bioteknologi yaitu teknik Kultur In Vitro [5].

Tahap penelitian Kultur In-Vitro mulai dari induksi embriosomatik dan enkapsulasi untuk produksi Benih Sintetik. Sel - sel kalus akan berkembang menjadi embrio melalui tahap - tahap morfologi yang khas tanpa melalui fase gamet. Perkembangan embrio somatik melalui tahap embrio disebut embriogenesis somatik [6]. Cara yang paling banyak diterapkan untuk meregenerasi planlet dari kultur jaringan adalah melalui embriogenesis somatik. Embriogenesis somatik merupakan suatu proses dengan sel somatik (baik haploid maupun diploid) berkembang membentuk tumbuhan baru melalui tahap perkembangan embrio yang spesifik tanpa melalui fusi gamet [7].

Kalus dan embriogenesis somatik yang terbentuk masih rentan terhadap kontaminasi apabila disimpan dalam waktu yang relatif lama. Oleh karena itu, upaya perlindungan dilakukan dengan menggunakan teknik enkapsulasi yang dapat menghasilkan benih sintetik [8].

Teknik Enkapsulasi merupakan teknologi yang prospektif dikembangkan untuk perbanyakan bibit dan konservasi. Teknik enkapsulasi merupakan teknik pembungkusan eksplan (embrio somatic atau meristem atau tunas pucuk) dengan suatu pembungkus khusus yang membuat eksplan tidak mudah rusak [9]. Pembungkus tersebut berperan sebagai endosperma yang mengandung sumber karbon, nutrisi dan zat pengatur tumbuh (ZPT) menstimulasi pertumbuhan dengan memberi isyarat kepada sel target untuk membelah atau memanjang [10]. Teknologi benih sintetik dapat memberi keuntungan antara lain penyimpanan yang tahan lama, mempermudah distribusi atau penyebaran, serta dapat melindungi benih dari hama penyakit [11].

Benih sintetik didefinisikan sebagai embrio somatik, tunas, agregat sel, atau jaringan lain yang dikemas dalam hydrogel dan dapat disemai sebagai benih yang memiliki kemampuan untuk menjadi tanaman di bawah kondisi in vitro atau ex vitro serta dapat disimpan dalam jangka waktu yang lama [11]. Produksi benih sintetik adalah teknik yang potensial untuk perbanyakan tanaman dan pelestarian, terutama tanaman komersial budidaya yang tidak menghasilkan benih, tanaman transgenik dan tanaman lain yang perlu dijaga sifat-sifat unggulnya [12].

Enkapsulasi pada umumnya menggunakan bahan gel untuk membentuk pembungkus (matriks kapsul) benih yang dapat melindungi embrio somatik tanpa merusak embrio namun masih memungkinkan embrio untuk berkecambah [13]. Kapsul harus cukup padat (rigid) dan kuat (durable) seperti benih biasa sehingga mudah ditangani untuk disimpan, dikirim atau ditanam. Matriks kapsul juga tidak boleh mudah bocor (leaky) sehingga ke dalam matriks kapsul dapat ditambahkan hara dan zat pengatur tumbuh. Penambahan hara atau zat pengatur tumbuh seperti ke dalam matriks kapsul diperlukan untuk membantu perkecambahan benih [13].

Kapsul yang digunakan pada teknik enkapsulasi terbuat dari alginate. Alginate berfungsi sebagai bahan antibakteri, hal ini sesuai dengan hasil penelitian bahwa bakteri tidak dapat tumbuh dalam media alginate dengan adanya zonasi daerah zona bening di sekitar membrane alginate [8].

Tujuan peneletian ini adalah untuk produksi benih sintetik dari embriosomatik guna melindungi benih dari kontaminasi dan penyediaan bibit dalam jumlah besar. 


\section{METODOLOGI PENELITIAN}

\section{A. Waktu dan Tempat}

Penelitian ini dilakukan di Laboratorium Biosains dan Teknologi Tumbuhan, Departemen Biologi, Fakultas Ilmu Alam, Institut Teknologi Sepuluh Nopember, Surabaya pada bulan Desember 2016 - Juni 2017.

\section{B. Alat dan Bahan}

Alat yang digunakan dalam penelitian ini adalah LaminarAir Flow (LAF), autoklaf, neraca analitik, hot plate, magnetic stirrer, lemari pendingin, $\mathrm{pH}$ Indicator, rak kultur, cawan petri, gelas beker, botol kultur, bunsen, sprayer, pinset, scalpel, tissue steril, pipet volume, pipet tetes, lap steril, kamera digital, keranjang sampahspidol permanent, erlenmeyer ukuran $1000 \mathrm{~mL}$ dan $250 \mathrm{~mL}$.

Bahan yang digunakan untuk penelitian ini adalah Kalus teh, alkohol 70\%, alkohol 96\%, klorox 3\%, Aquades, Medium MS, Agar pemadat, ZPT meliputi NAA, BAP dan GA3, HCl, $\mathrm{NaOH}$, antifungal, tissue, karet, label, dan plastik tahan panas. Bahan benih sintetik yaitu sodium alginat dan larutan $\mathrm{CaCl}_{2}$.

\section{Cara Kerja}

Penelitian ini terdiri atas beberapa tahapan yakni Sterilisasi alat dan ruang kerja, Induksi Embriosomatik dan Teknik enkapsulasi untuk memproduksi Benih Sintetik.

\section{Sterilisasi alat dan Ruang kerja}

Ruang kerja yang digunakan untuk inokulasi adalah LAF (Laminar Air Flow). Sterilisasi LAF dilakukan dengan cara menyalakan lampu UV (ultraviolet) pada LAF selama 2 jam untuk mematikan mikroorganisme atau kontaminan yang ada di dalam ruang kerja. Kemudian lampu UV dimatikan dan di nyalakan lampu neon serta blower yang ada pada LAF sehingga ruang kerja siap digunakan. Meja kerja dan peralatan inokulasi yang akan dimasukkan ke ruang kerja (LAF) disemprot alkohol terlebih dahulu beserta tangan yang akan masuk ke dalam LAF.

Sterilisasi peralatan yang akan digunakan untuk inokulasi dilakukan dengan menggunakan autoclave. Botol kultur dicuci dengan air terlebih dahulu, kemudian botol kultur direndam selama 1 malam pada air yang diberi dengan Sodium hipoklorit. Botol kultur dibilas dengan air dan kemudian dikeringkan. botol kultur, tisu, dan karet pentil masing-masing dimasukkan ke dalam plastik tahan panas, kemudian diikat kedua ujungnya dengan karet, untuk erlenmeyer dan kaca arloji tidak perlu dibungkus dengan plastik tahan panas. Pengaduk dan cawan petri dibungkus dengan kertas yellow pages. Kemudian semua perlatan untuk inokulasi dan pembuatan medium dimasukkan ke dalam autoclave untuk di sterilisasi, pada suhu $121^{\circ} \mathrm{C}$ dengan tekanan 1 atm selama 30 menit.

\section{Induksi Embriosomatik}

Kalus teh didapat dari laboratorium Jurusan Agroteknologi UPN Jawa timur dikultur dalam medium MS + BAP 1mg/l + NAA $0,1 \mathrm{mg} / \mathrm{l}$, medium dikondisikan dalam $\mathrm{pH} 5,8$, kemudian medium disterilisasi menggunakan autoclave pada suhu $121^{\circ} \mathrm{C}$ selama 20 menit dengan tekanan 1,2 atm. Eksplan diinokulasi ke medium di ruang LAF dalam keadaan steril. Kultur disimpan pada ruang dengan suhu $20-25^{\circ} \mathrm{C}$. Pada tahap ini mulai diamati perkembangan embriosomatik yang terbentuk. Embriosomatik yang telah mencapai fase torpedo akan dienkapsulasi.

\section{Teknik Enkapsulasi untuk Produksi Benih Sintetik}

Sodium alginat $4 \%$ ditambahkan pada medium MS cair bebas kalsium yang mengandung 3\% sukrosa. Enkapsulasi dilakukan dengan pencampuran embrio pada gel sodium alginat dan MS dengan hati-hati. Potongan eksplan noduler dimasukkan kedalam campuran sodium alginat dan MS cair lalu disedot menggunakan pipet pastik steril sekali pakai dengan posisi semua bagian embrio tertutupi oleh sodium alginat kemudian dimasukkan ke dalam larutan $50 \mathrm{mM} \mathrm{CaCl}_{2}$. Setelah terjadi pengerasan, butiran-butiran tersebut direndam ke dalam aquades untuk menghilangkan residu kalsium klorida.

\section{HASIL DAN PEMBAHASAN}

\section{A. Perkembangan Embriogenesis Somatik kalus (Camellia sinensis)}

Induksi embriogenesis somatik dilakukan secara tidak langsung, yaitu melewati fase kalus. Eksplan pada penelitian ini adalah kalus yang diinduksi dari daun. Induksi embriosomatik berlangsung selama 30 hari pada medium MS dengan penambahan zat pengatur tumbuh $0,1 \mathrm{mg} / 1 \mathrm{NAA}$ dan 1 $\mathrm{mg} / \mathrm{l}$ BAP. Setelah diinduksi, kalus memberikan respon embriogenesis yang berbeda-beda. Pengamatan fase Embrio somatik menggunakan Mikroskop Stereo dengan perbesaran $25 \mathrm{x}$.

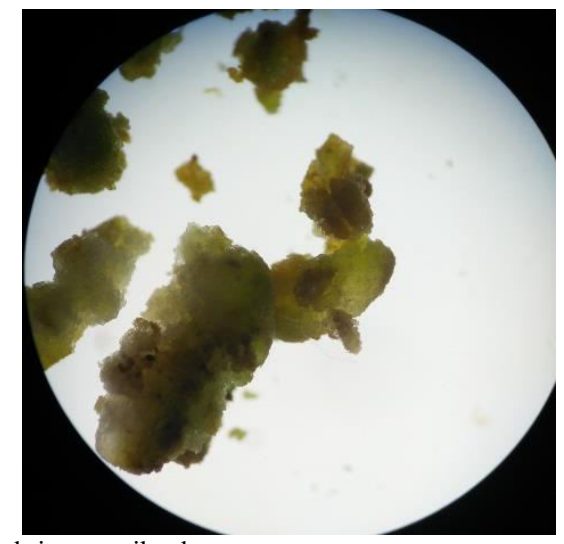

Gambar 1. Embrio somatik teh.

Komposisi medium yang digunakan, sesuai dengan penelitian [14] yaitu medium MS dengan kombinasi ZPT BAP $1 \mathrm{mg} / \mathrm{l}+\mathrm{NAA} 0,1 \mathrm{mg} / \mathrm{l}$. Kalus berkembang menjadi fase globular, hati dan torpedo. Menurut [15] sama seperti embrio zigotik yang berkembang dari penyatuan gamet jantan dan gamet betina, embrio somatik pun tumbuh dan berkembang melewati tahapan-tahapan yang sama.

Setelah di induksi selama 30 hari, kalus embriogenik berkembang menjadi fase globular, heart dan torpedo. Perbedaan respon tumbuh ini terjadi karena adanya interaksi antara zat pengatur tumbuh endogen yang berasal dari kalus dan eksogen yang ditambahkan ke dalam media. Menurut [16] perubahan keseimbangan zat pengatur tumbuh dalam sel jaringan eksplan terjadi akibat penambahan zat pengatur tumbuh secara eksogen. Interaksi antara zat pengatur tumbuh 
auksin dan sitokinin mengakibatkan terjadinya perbedaan fisiologis sel termasuk perbedaan metabolismenya, sehingga menghasilkan respon tumbuh yang berbeda, walaupun pada medium dengan penambahan ZPT yang sama. Menurut [17] Perkembangan kalus embriogenik menjadi embrio somatik merupakan aktivitas dari beberapa faktor. Dalam perkembangannya, kalus embriogenik melalui beberapa fase yaitu fase globular, hati, torpedo dan kotiledon

\section{B. Karakteristik Benih Sintetik}

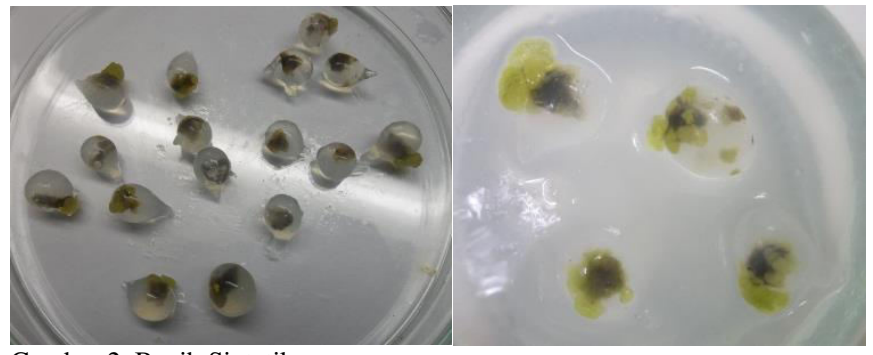

Gambar 2. Benih Sintetik.

Hasil penelitian menunjukkan bahwa natrium alginat $4 \%$ dapat membentuk kapsul yang cukup padat (rigid) pada larutan $\mathrm{CaCl} 2 \quad 100 \mathrm{mM}$. Tingkat kekerasan dapat mempengaruhi daya kecambah benih. Namun, kapsul yang terlalu lunak juga tidak diharapkan karena menyebabkan benih sintetik mudah hancur atau mengalami kebocoran.

Setelah dilakukan pengamatan, tekstur benih sintetik padat namun tidak terlalu keras, masih rentan rusak apabila tidak hati-hati ketika memindahkan. Semua benih sintetik yang terbentuk memiliki tekstur yang sama. Benih sintetik berwarna hijau kekuningan dengan diameter 5,5-5,7 $\mathrm{mm}$ dan berat basah 260-290 mg. Menurut [18] Proses pembentukan benih sintetik dilakukan menggunakan alginat karena tidak bersifat racun pada embrio atau bahan yang akan dienkapsulasi, kepadatannya dapat melindungi embrio yang masih rapuh, dan berperan sebagai penampung nutrisi yang digunakan embrio untuk bertahan hidup dan bahkan mempercepat pertumbuhannya [18].

Benih sintetik yang terbentuk berwarna putih kehijauan, selain itu embrio memiliki struktur kompak. Perubahan warna yang terjadi pada embrio akibat adanya pigmen dan dipengaruhi oleh nutrisi dan faktor lingkungan seperti cahaya [19]. Embrio berwarna kehijauan disebabkan karena kandungan klorofil, akibat interaksi NAA dan BAP, terutama BAP (sitokinin) yang berperan dalam pembentukan klorofil pada kalus serta faktor lingkungan yaitu paparan cahaya. Hal tersebut sesuai dengan pendapat Warna embrio menjadi putih kehijauan, disebabkan karena sel embrio sudah mulai membentuk kloroplas sehingga embrio menjadi lebih kompleks dan selanjutnya berdiferensiasi menjadi organ tertentu.

\section{KESIMPULAN}

Perbanyakan benih teh dalam jumlah besar dan dalam waktu yang singkat dapat dilakukan dengan teknik Kultur In vitro yaitu dengan induksi Embrio somatik. Embrio somatik yang dihasilkan masih rentan kontaminasi apabila disimpan dalam waktu yang lama sehingga perlu alternatif perlindungan dengan teknik enkapsulasi yang dapat menghasilkan Benih Sintetik.

\section{DAFTAR PUSTAKA}

[1] N. M. Fitra, "Analisis Efisiensi Produksi Tanaman Teh," Universitas Sumatera Utara, 2011.

[2] J. Tawoha, "Kandungan Senyawa Kimia pada Daun Teh (Camelia sinensis)," War. Penelit. dan Pengemb. Tanam. Ind., vol. 9, no. 3, 2013.

[3] W. Muljana, Bercocok Tanam Teh. Semarang: Aneka Ilmu, 1993.

[4] Wudianto, Membuat Setek, Cangkok dan Okulasi. Jakarta: Penebar Swadaya, 1987.

[5] D. F. Wetherell, Plant Tissue Culture Series. New Jersey: Avery Publishing Group Inc, 2008.

[6] M. A. J. Toonen and S. C. de Vries, Initiation of Somatic Embryos from Single Cells. In: Wang, T.L, and A. Cuming (ed.). Embryogenesis the generation of plant. Oxford: Bios Scientific Publishers Limited, 1996.

[7] E. G. William and Maheswara, "Somatic Embryogenesis Factor Influencing Coordinated Behavior of Cell as on Embriogenic Group," Ann. Bot., vol. 57, pp. 443-462, 1986.

[8] Redenbaugh and K. Synseeds, Application of synthetic seeds to crop improvement. London: CRC Press, 1992.

[9] P. K. Siong, S. Mohajer, and RM Taha, "Production of artificial seeds derived from encapsulated in vitro micro shoots of cauliflower, Brassica oleracea var. botrytis," Rom Biotechnol Lett, vol. 17, no. 4, pp. 75497556, 2012.

[10]R. P. Roostika I, Y. Supriati, I. Mariska, N. Khumaida, and G. Wattimena, "Pembentukan benih sintetik tanaman nenas," J Hort, vol. 22, no. 4, pp. 316-326, 2012.

[11]W. Muslihatin, N. Jadid, I. D. Puspitasari, and C. E. Safitri, "Growth of Vegetative Explant Moringa oleifera on Different Composition of Auxin and Cytokinin and its Synthetic Seed Germination," in AIP Proceeding of International Biologi Conference, 2016.

[12]G. V. . Saiprasad, "Artificial Seeds And Their Applications," Resonance, 2016. [Online]. Available: www.iisc.ernet.in/academy.

[13]M. Cheruvatur, N Najeeb, and T. Thomas, "In vitro propagation and conservation of Indian sarsaparilla, Hemidesmus indicus LR. Br. through somatic embryogenesis and synthetic seed production," Acta Physiol Plant, vol. 35, pp. 771-779, 2013.

[14]T. Seran, K. Hirimburegama, and MTK Gunasekare, "Encapsulation of embryonic axes of Camellia sinensis (L.) O. Kuntze (tea) and subsequent in vitro germination," J Hort Sci Biotechnol, vol. 80, pp. 154-158, 2005.

[15]H. Zulkarnain, Kultur Jaringan Tanaman, Solusi Perbanyakan Tanaman. Jakarta: Bumi Aksara, 2009.

[16] Rianawati and et al, "Embriogenesis Somatik dan Eksplan Daun Anggrek Phalaenopsis sp L., Somatic Embryogenesis from Leaf Eksplant of Phalaeonopsis Orchids," J. Agron. Indones., vol. 3, no. 37, pp. 240-248, 2009.

[17] Yelnititis, "Induksi Embrio Somatik Shorea pinanga Scheff. Pada Kondisi Fisik Media Berbeda," J. Pemuliaan Tanam. Hutan, vol. 7, no. 2, pp. 73 84, 2013.

[18]M. Rai, P. Asthana, S. Singh, V. Jaiswal, and U. Jaiswal, "The encapsulation technology in fruit plants - A review," Biotech Adv, vol. 27, p. 671-79\, 2009.

[19]D. A. Evans, W. R. Sharp, and C.E. Flick, Growth and Behavior of Cell Cultures. Embryogenesis and Organogenesis. in T.A. Thrope. Plant Tissue Culture Methods and Application in Agriculture. Acad. Press, 2003. 